\title{
AESTHETIC VALUES SUFISM IN FORMING OF THE SOLIDARITY IN URBAN COMMUNITY
}

\author{
Ichmi Yani Arinda Rohmah ${ }^{1}$ \\ ${ }^{1}$ Program Studi Ilmu Sosiologi, Universitas Nasional \\ email: ichmi@civitas.unas.ac.id
}

Korespondensi : ichmi@civitas.unas.ac.id

\begin{abstract}
Abstrak
Sufisme telah lama mengakar dalam beberapa kelompok masyarakat Indonesia. Satu hal yang unik bagi komunitas sufi di kota-kota metropolitan di Indonesia adalah bahwa penganutnya tidak hanya Muslim tetapi juga non-Muslim. Penelitian yang dilakukan oleh peneliti bermaksud untuk menguji keberadaan komunitas sufi di lingkungan masyarakat perkotaan, peneliti juga meneliti nilai-nilai estetika sufisme yang merupakan daya tarik masyarakat perkotaan untuk mengikuti ajaran sufi, dan peneliti melakukan penelitian tentang solidaritas komunitas yang dibentuk di komunitas perkotaan di Indonesia. Lokasi penelitian ini adalah di ibu kota Indonesia, Jakarta. Penelitian ini menggunakan jenis metode penelitian fenomenologis (kualitatif). Penggalian data lapangan menggunakan teknik wawancara, observasi, dan dokumentasi. Hasil penelitian menjelaskan bahwa ajaran sufisme masih ada di masyarakat perkotaan yang berada di tengah-tengah kehidupan kota metropolitan Jakarta, Indonesia. Komunitas sufi yang mengajarkan ajaran sufisme dapat diterima oleh sebagian besar komunitas perkotaan. Salah satu faktor pendorong yang membuat masyarakat urban mempelajari ajaran sufisme adalah nilai estetika sufisme, di samping itu ajaran sufisme dibangun dalam menciptakan solidaritas komunitas di antara masyarakat perkotaan yang sangat heterogen dalam latar belakang sosial budaya mereka. Nilai-nilai estetika sufisme dapat diperoleh oleh penganutnya melalui berbagai kegiatan religiusitas (dzikir, sholat, khotbah dan shalawat) dan seni sufism (musik, lagu, tarian, kreativitas fasion atau busana).
\end{abstract}

Kata kunci: sufisme, estetika, paguyuban, circle of friends, komunitas kota.

\begin{abstract}
Sufisme have long been rooted in some groups of Indonesian society. One thing that is unique to the Sufi community in metropolitan cities in Indonesia is that its adherents are not only Muslims but also non-Muslims. Research conducted by the researcher intends to examine the existence of Sufism in the urban community environment, the researcher also examines the aesthetic values of Sufism which are the attraction of urban society to follow Sufi teachings, and researchers conduct research on the solidarity of the community formed in urban communities in Indonesia. The location of this research is in the capital city of Indonesia, Jakarta. This study uses a type of phenomenological (qualitative) research method. Extracting field data using interview, observation, and documentation techniques. The results of the study explain that the teachings of Sufism still exist in urban communities that are in the midst of the life of the metropolitan city of Jakarta, Indonesia. The Sufism community that teaches Sufi teachings can be accepted by most urban communities. One of the driving factors that makes urban society to study the teachings of Sufism is the aesthetic
\end{abstract}


value of Sufism, besides that the Sufism teachings are built in creating community solidarity among urban communities who are very heterogeneous in their socio-cultural background. Sufism aesthetic values can be obtained by adherents through various religiosity activities (dhikr, praying, preaching and shalawat) and the arts of Sufism (music, songs, dances, fashion creativity).

Keywords: sufism, aesthetics, paguyuban, circle of Friends, urban communities.

\section{INTRODUCTION}

The State of Indonesia is one of the countries where the majority of the population is Muslim. People who embrace Islam are found in cities and villages. In Indonesia there are also various organizations and communities that have a background in Islamic teachings, including one of which is a Muslim community that studies Sufism. The existence of the Sufism community has also been around for a long time in Indonesia.

Sufism that developed in Indonesia is not much different from Sufism in Islamic countries in the Middle East, including the values of the teachings of Islam to the practice of worship. The difference between Sufism in Indonesia and Islamic countries in the Middle East and other countries is more in the pattern of adaptation of Sufism teachings with the culture of the people in Indonesia, this is also the case because every community in various countries has a variety of cultural and social characteristics.

Sufism have long been rooted in some groups of Indonesian Muslims, which encourages many religious education institutions such as pesantren to teach the values of Sufism through various forms of activities. In addition to educational institutions, in open societies such as metropolitan cities the teachings of Sufism are channeled through religious communities closer to the lives of metropolitan communities.

The characteristic of a metropolitan society is its attitude which is open to every change that occurs, as such it becomes one of social capital to be able to increase the social mobility of the community. In addition to being open, heterogeneity of the people always colors the metropolitan city, one of which is contextualized in Jakarta as the State Capital of Indonesia. Rapidly building social mobility always provides a special attraction for migrants. This has become one of the easiest ways for foreigners to enter Jakarta by bringing their influence in various fields, one of which is the socio-cultural sector.

Habitus Sufism in the Jakarta metropolitan city is an interesting thing to study. The teachings of Sufism with a nuance of religiosity can survive and develop in the midst of the growing popularity of popular culture and is loved by many metropolitan communities. Even the aesthetic values possessed by Sufism in various forms of art can compete with popular cultural arts in metropolitan cities. It is also inseparable from the characteristics of Sufism which can be open to change.

The aesthetic of Sufism through various arts and religious activities is one form of religious ideas accepted by the metropolis. Do not close the people from the bottom up to be able to accept the values of Sufism. As is the case with popular 
culture which is accepted by the metropolis publicly. Cultural cohesiveness in the life of the metropolis is a natural thing. Nothing is impossible if one culture can be acculturated with one another. The cohesiveness between popular culture and Sufism in the city is open enough to work together. Various forms of art that were born from Sufism thought can transform its aesthetic values through acculturation with popular culture that developed in the community.

The teachings of Sufism religiosity in which there are aesthetic values have a fundamental influence, one of which is to encourage people to be interested in learning about Sufism, including Muslim communities in the major cities of the State of Indonesia. The influence of people's interest in studying Sufism is also a factor in changing the social and cultural dynamics of urban communities that have heterogeneous characteristics.

The background becomes an interesting subject for researchers to conduct research on "Aesthetic Values Sufism in Forming of the Solidarity in Urban Community". Researchers conducted research in the capital city community in Jakarta, Indonesia which has diverse social and cultural characteristics and adheres to the teachings of Islam while learning about Sufism.

\section{RESEARCH METHOD}

This research uses qualitative research methods. Research location in the city of Jakarta. Researchers used participant observation, interview and documentation data collection techniques. Observations were made directly at the Sufi Community located in Kebayoran Baru, South Jakarta, Indonesia. The researcher made observations on all Sufi Community activities carried out. In the interview technique, researchers conducted open and structured interviews with informants. The main informant (key informant) is the chairman and founder of the Sufi Community, Muchsin Mulaela. Other informants are followers of Sufism and are active in activities carried out in the Sufi Community. The documentation done by researchers is to collect important documents that present information about Sufism thinking that is implemented, Sufism thinking implementation activities documents, and other documents that support according to the needs of researchers. This research was conducted for three months from 1 May 2019 to 31 July 2019.

\section{Urban Communities in Indonesia}

Urban communities in Indonesia especially in the city of Jakarta have social and cultural diversity. The social and cultural dynamics of society in Jakarta City has gradually undergone phases of change. As Talcott Parson explained in the book Ratna Saptari and Brigitte Holzner (1997) explained that to identify the phases of the development of social change from traditional to modern people can use five concepts, namely the first concept that has affective characteristics which are then positioned with affective neutral. The characteristics of the first concept show that the social relations of traditional communities are affective with the character of the people who are more personal, emotional, and interact directly or face to face. Whereas social relations of modern society have more impersonal characteristics, are free of emotions, and interact in indirect ways. 
The results of observations and identification on the dynamics of sociocultural changes in the city community, it can be seen that the characteristics of urban society, especially Jakarta, Indonesia has the characteristics of relationships between individuals more impersonal or individualist, interacting with each other more indirectly, and free of emotions in the sense of the community at Jakarta, Indonesia has the majority of thoughts that are open to change and use rationalization in thinking. It is thus based on the first concept in the phase of development of social change including categorized as modern society.

The second concept has a particularistic characteristic in traditional society which is positioned with a universalistic characteristic in modern society. The second concept realization in community life is that traditional societies tend to have characteristics that can work and relate more closely with fellow people who have the same background, coming from the same group. Whereas in modern society it has the characteristics of a more differentiated division of labor, having relationships and cooperation with fellow people from different social backgrounds. Communities in Jakarta City have the characteristics of the division of labor in accordance with the background of the educational status, expertise or competence possessed by urban communities.

The third concept has the characteristics of a collective orientation, the third concept can have the meaning of sacrifice and loyalty for the group, usually traditional societies have the characteristic of a social orientation that is a collective orientation. Opposite of the third concept is a self orientation which is characterized as a characteristic of modern society. Social relationships that are built in urban communities have the characteristics of self orientation, relationships that are oriented towards the goals of each individual.

The fourth concept is the status given (ascription) which is positioned with the status obtained (achievement). The realization of the fourth concept in traditional society, that is, traditional societies are valued and valued based on the social status that each individual has from birth. Whereas in modern society every individual is valued and valued for what he has achieved. Likewise, people in the city of Jakarta both in the realm of work and in the realm of other fields each individual is valued and judged based on the achievements he gets.

The fifth concept is functionally diffuse as opposed to functionally specific, the realization in traditional societies that the social role owned by each individual has no clear boundary, so that sometimes every individual has a dual role. Whereas in modern society the social roles of each individual differ according to the competence of each individual (Ratna Saptari, 1997). Likewise, the social role of each individual in the social environment of the people of Jakarta is based on their expertise or competence.

Theoretical concept of W.W. Rostow (1960) explained that the community in its development has several phases of change, namely: Phase I: traditional societies which are characterized as having dominant jobs in the agricultural sector, having clen systems, and fatalistic mentality. Second phase: Preconditions for takeoff. Third phase: Take off with the characteristics of economic growth and industrialization. The fourth phase: There is a push towards maturity, the fourth 
phase is characterized by the existence of an industry that is growing and advancing. The fifth phase: High mass consumption, which is marked by the availability of social security and welfare which is better than before (Ratna Saptari, 1997).

Seeing the reality of the environment in various fields of society in Jakarta, if it is identified with the theoretical concept of W.W. Rostow, it is known that the characteristics of the people of Jakarta are in the fourth and fifth phases. The development in the fourth phase of the Jakarta City industrialization began to develop by utilizing various types of modern information technology, then many commodities produced from the fruit of industrialization in the City of Jakarta, in addition the City of Jakarta became the administrative center of the State of Indonesia. In the fifth phase, it is known that the level of public consumption in Jakarta is quite high, which is also driven by the emergence of a digital-based market place. In addition, in Jakarta there are many shopping centers that are complex in nature, in fact one of the concepts of the Jakarta City market trade is the "Tanah Abang" market to be the largest market in Southeast Asia, in that market there are many export and import goods that can be bought and sold with the price is quite affordable.

The characteristics of urban communities in Jakarta in various economic, social, cultural and other fields can be concluded as a modern and open society with a variety of changes. The people who live in Jakarta City almost half the total urban population are immigrants who come from various regions of Indonesia and immigrants who come from various foreign countries. Socio-cultural heterogeneity in Jakarta City forms different patterns of social relations with other regions.

The presence of Sufism is also inseparable from the heterogeneity characteristics of urban society. The teachings of Sufism in Indonesia, including in the City of Jakarta, were adopted from Middle Eastern Countries which were identical with Islamic teachings. The inclusion of the teachings of Sufism is considered to have the teachings of religiosity with aesthetic values that are considered capable of creating peace between people, and helping adherents to get closer to God Almighty. The concept of Sufism teaches some community groups to include Sufism teachings in religious, social and educational communities or organizations. The same thing was done by one of the Islamic religious communities by incorporating the concept of Sufism located in Jakarta and being the object of this research, the Sufi Community which the researchers made as research objects has a special building to carry out routine religious activities, namely the "Rumi Cafe" building.

\section{The Aesthetic Values of Sufism}

Ibrahim Ali Fauzi explained in his book that modernism was a reaction to modernity. Modernism as a form of response in the aesthetic field, the response is not in the realm of science and technology, but in the realm of philosophy, aesthetics, and language. Conservative modernism can occur in the realm of religion. While radical and revolutionary modernism can occur in the realm of culture, especially art (Ibrahim Ali Fauzi, 2003). In this case the relationship between modernism and the presence of Sufism in Jakarta can be considered 
conservative. The purpose of conservative nature is to be able to maintain the values that exist in the teachings of Sufism. The existence of modernity can also be a medium in the process of socialization of Sufism teachings about Islam to urban communities.

One of the aesthetic values in the teachings of Sufism can be seen clearly in the culture realized by members of the Sufism community at Rumi Café, South Jakarta. Culture can be in the form of ideas or ideas, actions, and artifacts. Sufism culture in the form of actions or actions can be in the form of Sufi dance movements, and artifacts can be in the form of objects used by Sufis such as hats and Sufi clothing. In the book Fahmi Tharaba also explained that religion has a relationship with culture, there are three cultural functions in the realm of religiosity, namely: a) religious personality expressions, namely expressions of one's faith in adherents of religion that can be realized through certain cultural patterns, b) collective religious expressions, namely a person in expressing his faith and carried out collectively or together with fellow religious people can not be separated from the cultural context of his nation, in this case the socio-cultural concept applies, c) religious symbols, namely symbols that are sacral or spiritual and shaped in the form of symbols material used to provide an explanation (Fahmi Tharaba, 2016).

Geertz in Fahmi Tharaba's book explains that in an anthropological view it is said that religion is a cultural system that can provide deep meaning about human existence. Geertz writes:

"Religion is a symbol that serves to strengthen the mood and motivation that is strong, deep and unquenchable in humans by formulating a conception of the general order of existence and wrapping that conception with an aura of actuality that for feelings and motivations seems realistic" (Fahmi Tharaba, 2016: 128).

Islamic teachings taught by Sufis with the concept of identical Sufism have a deep sense of religiosity. Sufism teaches about the religion of Islam that is peaceful, has the value of deep love for God Allah SWT, Sufism instills aesthetic values that bring peace to the hearts of the Sufi personalities because they draw closer to God. In addition, the aesthetic value of Sufism also encourages mutual caring towards fellow human beings without discriminating the background of their social status.

Thomas F. O'Dea (1995) in the book Fahmi Tharaba explained that the correlation between religion and culture can be seen through five aspects, namely: First, the relationship of religion and culture as a dramatic concept that has a function as a giver of sense of flux or planting message. Second, religion and culture as a form of symbolic transformation for adherents of religion in the understanding of deeper experiences about matters that are natural or super natural. Third, religion as a defense system to fight the mind that is full of doubts. Fourth, religion as a guidance system that has normative elements that provide answers to all thoughts and deeds. Fifth, religion has a range of economic symbols that place symbolic values with different weights (Fahmi Tharaba, 2016). 
Interaction that is built between adherents of Sufism is as a symbol of action to realize Sufism values taught in the community. In the book Kenneth Allant (2006: 17) also mentioned that symbolic interactions among others can indicate the purpose of showing objects, the use of symbols as an act of response, to read and interpret the behavior of others and make it as a stimulus for further action.

Based on Thomas F.O'Dea's theoretical concept, researchers identified Sufism teachings that correlate the concept of socialization about Islamic teachings using Sufism culture products, the results of the identification are: First, Sufism culture has a deep meaning containing messages and religious values that encourage Sufis to can be closer to God Almighty. Second, Sufism culture has a form of symbolic transformation in expressing natural and super natural religious experience. Third, Sufism exists to fuse thoughts that are wavering from his faith in God Almighty. Fourth, the teaching of Sufism as a guidance system that has a normative element that is able to provide answers to all thoughts and actions taken by religious people. Fifth, sufism also has a range of economic symbols that place values in the form of symbolic with different weights, but within the scope of these economic symbols do not have the aim to transact cultural products of Sufism with values that are materialistic.

\section{Sufism In Forming of The Solidarity in Urban Community}

The concept of community society has been explained by Ferdinand Tonnies. Circle of Friends is a word that comes from Indonesian, while in German it is called gemeinschaft. The opposite of the word association is patembayan or in German it is called Gesellschaft. Basically, Ferdinand Tonnies (1912) explained that the paguyuban or gemeinschaft is a characteristic of people who live in rural environments, while patembayan or gesellschaft is a characteristic of urban society.

Paguyuban or gemeinschaft community has identical characteristics with the community that has social ties that are personal, the community has a social relationship based on the family system, is mutual cooperation, the community still maintains traditions that have existed since its ancestors. While patembayan or gesellschaft societies have identic characteristics with people who have impersonal social ties, social relations are based on the interests of each individual or different groups, old traditions that are conventional tend to be abandoned.

The presence of Sufism teachings in the Sufi community environment in the Rumi Café in Jakarta has a strong enough influence to bind or integrate the social personality relationship between members of the Sufi community, even though the members of the community have different religions, namely Islam and non-Islam. The Sufi community which is the object of this research has the flexibility in recruiting members in the community. Based on information from informants through in-depth interviews, that members of the Sufism community in Rumi Café are those who voluntarily want to become members of the Sufi community, the goal of Sufism community members participating in activities within the Sufism community is to draw closer to God and establish brotherhood with fellow humans, this is done by participating in various activities in the Sufism community. The characteristics of Sufism teachings provide a great opportunity for anyone who 
wants to follow the agenda in the Sufism community, even for non-Muslim followers, this is what makes Sufism teachings able to build strong social integrity among religious communities.

Elly M. Setiadi (2011) explained that there are types of social integration, namely family integration, kinship integration, association integration, community integration, and ethnic integration (Adon Nasrullah Jamaludin, 2015). Seeing the integration formed in the Sufism community, the integration created is the integration of associations.

There are factors driving social integration, namely primordial, sacred, figures, unity in diversity, economic development, group homogeneity, group size, sociogeographic mobility, effectiveness and efficiency of communication (Adon Nasrullah Jamaludin, 2015). Identifying the integration formed between members of Sufism in the Rumi Café community, it can be concluded that the integration formed is based on the characterization, unity in diversity, effectiveness and efficiency of communication between members of the Sufism community in the Rumi Café.

Social integration that is formed in urban communities through Islamic teachings socialized with the concept of Sufism is able to change the characteristics of urban communities from patembayan to paguyuban, although some patembayan characteristics are also still owned by urban communities involved in Sufism communities, patembayan characteristics that are difficult to eliminate are social roles and assessments given to each individual based on competencies possessed by each individual, as well as conventional social systems. While the characteristics of the community formed in the social life of members of the Sufism community are the fusion of individualism and the development of mutual cooperation and social integration between members who have different social statuses and roles.

It is explained in the book Adon Nasrullah Jamaludin that there are three basic religious harmony in Indonesia, namely Pancasila, namely the principle of Godhead, the 1945 Constitution Article 28 verse 1 reads: everyone is free to embrace religion and worship according to their religion, choose education and teaching, choosing a job, choosing citizenship, choosing a place to live in the territory of the State and leaving it, as well as the right to return and paragraph 2 which reads every person has the right to freedom of belief, to express thoughts and attitudes, in accordance with his conscience. This is confirmed in article 29 paragraph 1 which reads: "The State is based on the Almighty God", and paragraph 2 which reads: The State guarantees the independence of each population to embrace their respective religions and to worship according to the teachings of their religion and beliefs. Article 22 of Law (Undang-Undang No.39 of 1999) concerning Human Rights, namely 1) "everyone is free to embrace their respective religions and to worship according to their religion and beliefs :, 2)" The state guarantees the freedom of everyone to embrace their respective religions and to worship according to his religion and beliefs ".

The Government of Indonesia applies the terminology of the concept of harmony which includes three concepts, namely: (1) internal harmony of religious communities, (2) inter-religious harmony, (3) inter-religious harmony with the government. (Adon Nasrullah Jamaludin, 2015). 
Opponents of social integration that create order in people's lives are social disintegration that can create conflict. Hendropuspito in the book Adon Nasrullah Jamaludin explained that there were four forms of social conflict that originated from religion, namely (a) Differences in doctrine and mental attitude, (b) Differences in ethnicity and religious races, (c) Differences in cultural levels, (d) Problems of the majority and minority religious groups (Adon Nasrullah Jamaludin, 2015).

Islamic teachings that are taught by using the concept of Sufism have a function such as that explained by Thomas F. O'Dea in the book Syamsuddin Abdullah and Adon Nasrullah Jamaludin about religion that has a function, namely among others religion functions as a means to gain knowledge about the outside world that cannot be reachable by humans (beyond), and religion also functions as a means of ritual that can connect humans with things beyond their reach so that it is believed to be able to guarantee happiness and safety for humans. Besides religion also serves to purify the rules and values in the life of the community that has been formed (Adon Nasrullah Jamaludin, 2015).

\section{CONCLUSION}

The concept of Sufism teaches some community groups to include Sufism teachings in religious, social and educational communities or organizations. The same thing was done by one of the Islamic religious communities by incorporating the concept of Sufism which is located in Jakarta, namely "Rumi Cafe". Islamic teachings taught by Sufis with the concept of identical Sufism have a deep sense of religiosity. Sufism teaches about the religion of Islam that is peaceful, has the value of deep love for God Allah SWT, Sufism instills aesthetic values that bring peace to the hearts of the Sufi personalities because they draw closer to God. Social integration that is formed in urban communities through Islamic teachings socialized with the concept of Sufism is able to change the characteristics of urban communities from patembayan to paguyuban, although some patembayan characteristics are also still owned by urban communities involved in Sufism communities, patembayan characteristics that are difficult to eliminate are social roles and assessments given to each individual based on competencies possessed by each individual, as well as conventional social systems. While the characteristics of the community formed in the social life of members of the Sufism community are the fusion of individualism and the development of mutual cooperation and social integration between members who have different social statuses and roles.

\section{REFERENCE}

Allan, Kenneth. (2006). Contemporary Sosial and Sociological Theory Visualizing Sosial Worlds. London: Sage Publication Ltd.

Fauzi, Ibrahim Ali. (2003). Jurgen Habermas. Jakarta Selatan: Teraju. 
Jamaludin, Adon Nasrullah. (2015). Agama \& Konflik Sosial (Studi Kerukunan Umat Beragama, Radikalisme, dan Konflik Antarumat Beragama). Bandung: Pustaka Setia.

Odea F, Thomas. (1995). Sociology of Religion. Jakarta: Bumi Aksara.

Rostow, W.W. (1960). The Stages of Economic Growth. Cambdrige University Press. UK.

Saptari, Ratna \& Brigitte Holzner. (1997). Perempuan Kerja dan Perubahan Sosial (Sebuah Pengantar Studi Perempuan). Jakarta: PT. Pustaka Utama Grafiti.

Setiadi, Elly M. (2011). Pengantar Sosiologi: Pemahaman Fakta dan Gejala Permasalahan Sosial. Jakarta: Kencana.

Tharaba Fahim. (2016). Sosiologi Agama (Konsep, Metode Riset, dan Konflik Sosial). Malang: Madani.

Tonnies, Ferdinand. (1912). Gemein Schaft und Gessellschaft. Leipzig.

Undang-Undang No. 39 of 1999 tentang Hak-Hak Azazi Manusia.

Undang-Undang Dasar 1945. 